\title{
Erratum to: Isolation of RNA from Field-Grown Jute (Corchorus capsularis) Plant in Different Developmental Stages for Effective Downstream Molecular Analysis
}

Pradipta Samanta • Sanjoy Sadhukhan •

Subrata Das • Alpana Joshi • Soumitra K. Sen •

Asitava Basu

Published online: 16 July 2011

(C) Springer Science+Business Media, LLC 2011

Erratum to: Mol Biotechnol

DOI 10.1007/s12033-011-9376-8

Figure 5 was mistakenly duplicated in place of Figure 4. The correct Figure 4 appears here. The publisher regrets the error.

The online version of the original article can be found under doi: 10.1007/s12033-011-9376-8.

P. Samanta $\cdot$ S. Sadhukhan $\cdot$ S. Das $\cdot$ A. Joshi $\cdot$

S. K. Sen · A. Basu $(\bowtie)$

Advanced Laboratory for Plant Genetic Engineering, Indian Institute of Technology, Kharagpur 721302, India

e-mail: asitavab@yahoo.co.in

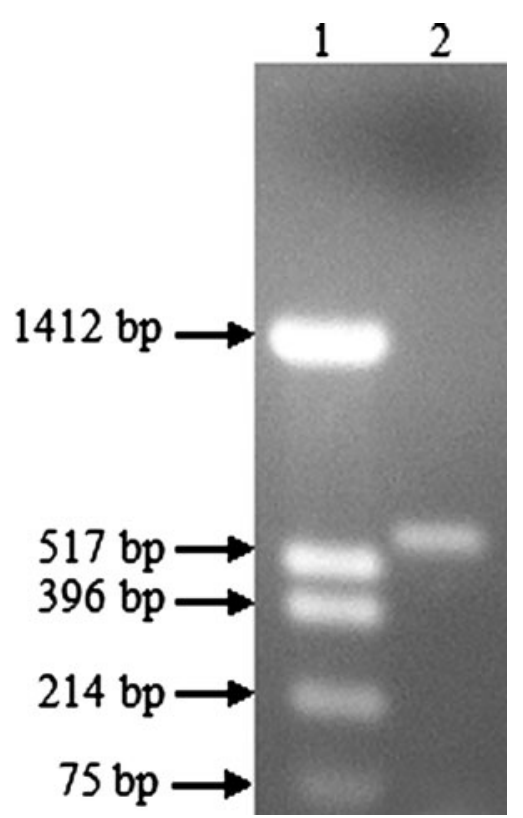

Fig. 4 Reverse transcriptase polymerase chain reaction of 4CL gene. Lane 1, HinfI digested pUC18 as DNA molecular weight marker and lane 2, amplified 4CL cDNA fragment 